\title{
10
}

\section{The Witch-Girl and the Shrew}

[This chapter of Reay's manuscript is missing.] 
This text is taken from Wives and Wanderers in a New Guinea Highlands Society: Women's lives in the Wahgi Valley, by Marie Olive Reay, published 2022 by ANU Press, The Australian National University,

Canberra, Australia.

doi.org/10.22459/WWNGHS.2022.10 